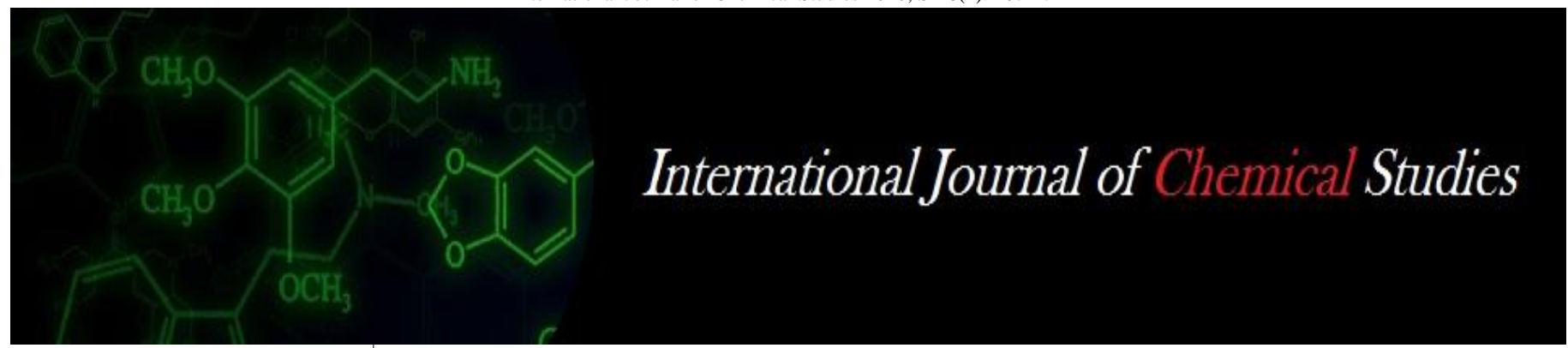

P-ISSN: 2349-8528

E-ISSN: 2321-4902

www.chemijournal.com

IJCS 2020; SP-8(4): 267-271

(C) 2020 IJCS

Received: 10-05-2020

Accepted: 14-06-2020

Tajamul Islam

College of Temperate Sericulture,

Mirgund, Sher-e-Kashmir University of Agricultural Sciences and

Technology of Kashmir, SKUAST-K Shalimar, Srinagar, Kashmir, Jammu and Kashmir, Indi

\section{Irfan Latif Khan}

College of Temperate Sericulture,

Mirgund, Sher-e-Kashmir University

of Agricultural Sciences and

Technology of Kashmir, SKUAST-K

Shalimar, Srinagar, Kashmir, Jammu

and Kashmir, India

\section{Nisar Ahmed Ganie}

College of Temperate Sericulture,

Mirgund, Sher-e-Kashmir University

of Agricultural Sciences and

Technology of Kashmir, SKUAST-K

Shalimar, Srinagar, Kashmir, Jammu

and Kashmir, India

\section{Khursheed Ahmed Sahaf}

College of Temperate Sericulture,

Mirgund, Sher-e-Kashmir University

of Agricultural Sciences and

Technology of Kashmir, SKUAST-K

Shalimar, Srinagar, Kashmir, Jammu and Kashmir, India

Nayeema Jan

College of Temperate Sericulture,

Miround, Sher-e-Kashmir University

of Agricultural Sciences and

Technology of Kashmir, SKUAST-K

Shalimar, Srinagar, Kashmir, Jammu

and Kashmir, Indi

Mehreen Manzoor Gora

College of Temperate Sericulture,

Mirgund, Sher-e-Kashmir University

of Agricultural Sciences and

Technology of Kashmir, SKUAST-K

Shalimar, Srinagar, Kashmir, Jammu

and Kashmir, India
Corresponding Author:

Tajamul Islam

College of Temperate Sericulture,

Mirgund, Sher-e-Kashmir University of Agricultural Sciences and

Technology of Kashmir, SKUAST-K

Shalimar, Srinagar, Kashmir, Jammu

and Kashmir, India

\section{Impact of egg albumen (egg white) fortified mulberry leaf on rearing and some cocoon parameters of silkworm, Bombyx mori L. (CSR6 $\times$ CSR26 $) \times($ CSR2 $\times$ CSR27 $)$ double hybrid}

\author{
Tajamul Islam, Irfan Latif Khan, Nisar Ahmed Ganie, Khursheed Ahmed \\ Sahaf, Nayeema Jan and Mehreen Manzoor Gora
}

DOI: https://doi.org/10.22271/chemi.2020.v8.i4e.10034

\begin{abstract}
Fortification of mulberry leaf with egg albumen and its impact on commercial characteristics of Silkworm (Bombyx mori L.) was conducted at College of Temperate Sericulture Mirgund SKUAST-K during spring 2017. The silkworm double hybrid $($ CSR6 $\times$ CSR26) $\times($ CSR2 $\times$ CSR27) was reared on mulberry leaves fortified with aqueous egg albumen solution daily once during fourth and fifth instar. Four different concentrations of egg albumen viz., 5\%,10\%, 15\% and 20\% were tested. Egg albumen improved all the rearing and cocoon characteristics of the silkworm. T5 (20\% egg albumen) significantly improved all the parameters registering lowest total larval duration, highest weight of ten mature larvae, cocoon weight, shell weight and shell ratio of 25.33 days, $57.96 \mathrm{~g}, 2.32 \mathrm{~g}, 52.65 \mathrm{cg}$ and $22.52 \%$ respectively.
\end{abstract}

Keywords: Silkworm, double hybrid, egg albumen, fortification, significant, cocoon parameters

\section{Introduction}

Sericulture or silk farming is the rearing of silkworms for the production of silk. Being agro based industry it is ideally suited for the socio economic development of people living in rural areas. Sericulture industry has potential to generate employment for the people worldwide and contributes to GDP (Gross Domestic Product) of many countries viz., India, China, Thailand (Chen, 2003; Chen and $\mathrm{Gu}, 2006)^{[1,2]}$. Sericultural practices started 5000 years ago in Chantong region of China and from there it reached to other neighbouring countries like Korea, Japan and Vietnam (Needham, 1954) ${ }^{[3]}$. Silk is the most beautiful textile in the world with unmatched splendour, natural lusture, intrinsic affinity for dyes, great absorbance, light weight, soft touch and long durability. Due to these distinctive features silk is called as the "Queen of Textiles". India is the only country in the world which produces all the five types of commercial silks viz., Mulberry, Tropical Tasar, Oak Tasar, Eri and Muga, among which Muga having the golden yellow appearance is produced only by India. In India Mulberry sericulture is practiced in the four traditional states viz., Karnataka, Andhra Pradesh, West Bengal, Tamil Nadu and Union territory of Jammu and Kashmir. India occupies the second position in the production of raw silk with the annual turnover of 35,468 MT (Anonymous, $2019)^{[4,5]}$. In J\&K 2800 villages are practicing sericulture activities and 30,300 families are associated with the sericulture and producing $118 \mathrm{MT}$ of raw silk (Anonymous, 2019) ${ }^{[4,5]}$.

Silkworm Bombyx mori L. feeds exclusively on the mulberry leaves. Proteins form the chief constituent of mulberry leaf along with carbohydrates, vitamins, sterols, minerals and phagostimulants etc. Silkworm being monophagous insect feeds only on the mulberry leaves as it contains the chemical called as morin (Triubhuvan and Mathur, 1989) ${ }^{[6]}$. The quality and quantity of leaf consumed by the larvae greatly influences the production of cocoons. Various studies in the past and present on silkworm nutrition have established that it is the quality of leaf that ultimately reflects on growth and development of silkworm as well as in overall silk production. Lack of intake of potassium, calcium and phosphorus by silkworms severely affects the silkworm larval weight, cocoon and other silk parameters (Patil, 2003) ${ }^{[7]}$. 
Nutrition involves chemical and physiological activities which transform food elements into body elements. Insect nutrition is concerned primarily with the biochemical substances present in food stuff necessary to set in motion and maintain long series of metabolic processes that provide energy and metabolites for growth, development and other vital functions (House, 1966) ${ }^{[8]}$. Legay (1958) ${ }^{[9]}$ stated that silkworm nutrition is considered the major area of research in sericulture. The success of quality cocoon crop depends exclusively on the nutrition of silkworm (Nagesh and Deviah, 1996) ${ }^{[10]}$. It has been proved beyond doubt that silkworms require proteins, carbohydrates and minerals for normal growth, survival and for increased silk production. If these essential nutrients are not present in the required amount in the mulberry leaves the silkworms encounter problems in larval growth and silk synthesis (Sengupta, 1972) ${ }^{[11]}$. The present study aimed at using albumen of hen egg as a supplement to improve the quality of mulberry leaves. The eggs are highly nutritious and easily available to the silkworm rearers. Powrie (1985) [13] estimated that Egg albumen contains 18 amino acids, which includes all the essential amino acids. Hundred grams of egg, or slightly less than $1 / 2$ cup, contain 5.5 grams of alanine, 5.0 grams of isoleucine, 6 grams of serine, 4.5 grams of arginine, 6.8 grams of leucine, 3.4 grams of threonine, 6 grams of aspartic acid, 4.6 grams of lysine, 1.2 grams of tryptophan, 1.9 grams of cysteine, 3.0 grams of methionine, $3.2 \mathrm{~g}$ of tyrosine, 10.9 grams of glutamic acid, 4.9 grams of phenylalanine, 6 grams of valine, 1.7 grams of histidine, 2.9 grams of proline, and 2.9 grams of glycine. The egg albumen contains about 4 grams of protein, $55 \mathrm{mg}$ of sodium and besides some calories. A single egg white also offers 1.3 micrograms of folate, $6.6 \mathrm{mg}$ of selenium, $2.3 \mathrm{mg}$ of calcium, $3.6 \mathrm{mg}$ of magnesium, and 4.9 $\mathrm{mg}$ of phosphorus and $53.8 \mathrm{mg}$ of potassium.

\section{Materials and Methods}

\section{Location of research trial and proper methodology}

The research trial was conducted at College of Temperate Sericulture, Mirgund, SKUAST-K Shalimar, Kashmir. The rearing room and appliances were throughly disinfected and the rearing of Silkworm conducted as per the package of practices for silkworm rearing upto the third instar (Anonymous 2003) ${ }^{[13]}$. The larvae were fed with normal mulberry leaves till $3^{\text {rd }}$ moult and then on albumen fortified leaves from fourth instar onwards. Mulberry leaves were dipped in the aqueous solution of egg albumen and after keeping in shade for half an hour to remove excessive wetness, the leaves were fed to larvae from the first day of fourth instar. Daily one feed of the egg albumen treated leaves and three feeds of normal mulberry leaf was given to the silkworms till spinning of cocoons.

\section{Test insect and treatment details}

Silkworm double hybrid $($ CSR6 $\times$ CSR26) $\times($ CSR2 $\times$ CSR27) was used for feeding of the egg albumen fortified mulberry leaf upto spinning of the cocoons. Upto third instar normal leaves and in the fourth and fifth instar egg albumen fortified mulberry leaves were fed for the rearing of silkworms. Treatments maintained were $\mathrm{T}_{0}$ (Control), $\mathrm{T}_{1}$ (Dipped in distilled water), $\mathrm{T}_{2}$ (5\% Egg Albumen), $\mathrm{T}_{3}(10 \%$ Egg Albumen), $\mathrm{T}_{4}\left(15 \%\right.$ Egg Albumen) and $\mathrm{T}_{5}(20 \% \mathrm{Egg}$ Albumen). 4 replications in each treatment were maintained and in each replication 200 worms were kept throughout the silkworm rearing upto spinning of cocoons. 28 experimental units (rearing trays) were maintained throughout the silkworm rearing upto cocoon formation. The parameters were calculated by the following formulae:

\section{Total larval duration (days)}

Total larval duration was calculated as the time taken from brushing till spinning of cocoon.

\section{Weight of ten mature larvae (g)}

Ten mature larvae were taken randomly from each treatment of each replication and weighed on a digital balance.

Yield of cocoons/10000 larvae by weight $(\mathrm{kg})$

It was calculated by the following formula:

Weight of cocoons harvested per replication Number of worms kept after $3^{\text {rd }}$ moult $\times 10000$

Yield of cocoons/10000 larvae by number

It was calculated by the following formula:

$\frac{\text { Number of cocoons harvested per replication }}{\text { Number of worms kept after } 3^{\text {rd }} \text { moult }} \times 10000$

\section{Cocoon Weight (g)}

Twenty cocoons (ten male and ten female) were taken randomly from each treatment of each replication on the $7^{\text {th }}$ day of mounting. The cocoons were weighed one by one on digital balance and then average cocoon weight was calculated.

\section{Shell weight (cg)}

Twenty cocoons already weighed for cocoon weight were cut open at the top in order to remove pupae. The weight of each shell was taken on a digital balance in order to calculate the average shell weight for each treatment.

Shell ratio $(\%)$

Shell ratio was calculated by the following formula:

Shell ratio $=\frac{\text { Shell weight }}{\text { Cocoon weight }} \times 100$

\section{Statistical analysis}

The data was compiled and the statistical analysis of the data was done by the standard method and the significance was checked at $5 \%$ level.

\section{Results and Discussion \\ Total larval duration (days)}

The larval duration was shortest (25.33 days) in $\mathrm{T}_{5}$ (20\% egg albumen) which was significantly different from all other treatments. The larval duration was longest (26.12 days) in $\mathrm{T}_{0}$ (control) being statistically at par with $\mathrm{T}_{1}$ (dipped in water) (Table 1). The shortest larval duration in case of $\mathrm{T}_{5}$ might be through fortified leaves due to the increased availability of amino acids in the larval food and larval haemolymph which inturn led to shortening of larval duration. The present findings are in line with the findings of Horie and Watanabe (1983) [14] who reported shortening of larval duration by supplementation with soybean protein. Similar result was also reported by Sekar (1995) ${ }^{[15]}$. Murari et al. (2008) ${ }^{[16]}$ also reported that the application of $C$. sativus extract to fifth instar larvae significantly reduced the larval duration. 


\section{Weight of ten mature larvae (g)}

The weight of ten mature larvae was maximum $(57.96 \mathrm{~g})$ in $\mathrm{T}_{5}$ (20\% egg albumen) which was significantly different from all other treatments. The minimum weight of ten mature larvae (46.05g) was recorded in case of $\mathrm{T}_{0}$ (control) (Table 1). The increase in weight of ten mature larvae might be due to the enhancement of bio-availability of proteins, trace minerals, vitamins and glucose that are beneficial to insects and also for their better growth and development. Sarker (1993) ${ }^{[17]}$ also reported improvement in the growth of silkworm larvae feeding with mulberry leaves supplemented with different nutrients. The present findings are in line with the findings of Hossain et al. (2015) ${ }^{[18]}$ who supplemented mulberry leaves with cow milk and reported that larval weight increased by $208 \%$ over control. The present findings are also in conformity with the findings of Alagumalai et al. (1991) [19] and Mala et al. (2017) ${ }^{[20]}$ who supplemented the mulberry leaf with aloe vera.

\section{Cocoon yield by weight (kg)}

The cocoon yield by weight was maximum $(20.90 \mathrm{~kg})$ in $\mathrm{T}_{5}$ (20\% egg albumen) which was significantly different from all other treatments. The cocoon yield by weight was minimum (18.12kg) in $\mathrm{T}_{0}$ (control) (Table 1). The increased cocoon yield by weight may be because of significant increase in cocoon weight by protein supplementation through egg albumen. Nalini et al. (1994) ${ }^{[21]}$ and Rajana and Puttaraju (2000) ${ }^{[22]}$ have also reported increased cocoon yield by weight due to supplementation of mulberry leaf with soyaflour.

\section{Cocoon yield by number}

Regarding the cocoon yield by number no significant difference was observed among the different treatments. However the values ranged from 8790 in $\mathrm{T}_{2}(5 \% \mathrm{egg}$ albumen) to 9121 in $\mathrm{T}_{4}(15 \%$ egg albumen) (Table 1$)$.

\section{Cocoon weight (g)}

In the present study cocoon weight was highest $(2.32 \mathrm{~g})$ in $\mathrm{T}_{5}$ (20\% egg albumen) which was significantly different from all other treatments and the lowest cocoon weight $(2.06 \mathrm{~g})$ was recorded in $\mathrm{T}_{0}$ (control) (Table 2). The significant improvement in cocoon weight might be due to the egg albumen, which contains many nutrients that might have led to the improvement in cocoon weight. The present findings are in line with the findings of Hossain et al. (2015) ${ }^{[18]}$ and Amit et al. (2015) ${ }^{[23]}$ who supplemented mulberry leaves with cow milk and waste pupal protein and reported that cocoon weight increased by $18 \%$ and $13.26 \%$ over control respectively. Sujatha and Rao (2003) ${ }^{[24]}$ reported that the application of $C$. longa stem extract on fourth instar larvae resulted in higher cocoon weight. The present findings are also in conformity with the findings of Chamundeshwari and Radhakrishnan (1994) ${ }^{[25]}$, Mujumdar and Medda (1995) ${ }^{\text {[26] }}$ and Mala et al. (2017) [20] who have supplemented the mulberry leaf with zinc and nickel, tyrosine and aloe vera respectively.

\section{Shell weight (cg)}

The shell weight was maximum $(52.65 \mathrm{cg})$ in $\mathrm{T}_{5}(20 \% \mathrm{egg}$ albumen) which was significantly higher than all other treatments. The minimum shell weight $(40.60 \mathrm{cg})$ was

recorded in $\mathrm{T}_{0}$ (control) (Table 2). The improvement in shell weight might be due to increased nutritional efficiency of food which is utilized for the maximum silk protein content of the cocoon shell. The actual silk fibre fibroin is derived from four kinds of amino acids viz., Alanine, Serine, Glycine and Tyrosine that come from the food of silkworm. These amino acids are easily provided to the silkworm through fortification of mulberry leaf with egg albumen. The present findings are in conformity with the findings of Amit et al. (2015) ${ }^{[23]}$ who supplemented mulberry leaves with cow milk and reported that shell weight increased by $23.33 \%$ over control. The present findings are in line with the findings of Mahesha (1999) ${ }^{[27]}$ who reported improvement in shell weight due to the application of $P$. hysterophorus and $T$. procumbens extract. The present findings are in also conformity with the findings of Fatima et al. (2008) ${ }^{[28]}$ who reported maximum shell weight due to the application of aloe vera gel extract.

\section{Shell ratio (\%)}

Shell ratio which gives an indication of the quantity of silk that could be obtained from a particular lot of cocoons, is an important commercial trait. This trait is generally given preference in commercial marketing of cocoons. In the present study the shell ratio was highest $(22.52 \%)$ in $\mathrm{T}_{5}(20 \%$ egg albumen) which was significantly different from all other treatments. The shell ratio was lowest $(20.20 \%)$ in $\mathrm{T}_{0}$ (control) (Table 2). The increased shell ratio might be due to increased shell weight which got influenced by the nutrients present in the egg albumen. This could be attributed to the stimulatory effect of these nutrients on protein synthesis in the silk gland during larval period. The present findings are in line with the findings of Hossain et al. (2015) ${ }^{[18]}$ and Amit et al. (2015) ${ }^{[23]}$ who supplemented mulberry leaves with cow milk and waste pupal protein and reported that shell percentage increased by $11 \%$ and $9.01 \%$ over control respectively. These findings are also in conformity with the findings of Horie and Watanabe (1983) ${ }^{[14]}$ who reported increased shell ratio due to protein supplementation of mulberry leaves with amino acids.

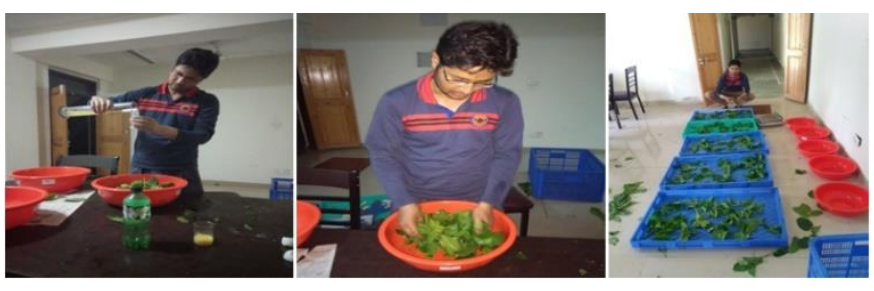

Fig 1: Preparation of different concentrations of egg albumen and its fortification with mulberry leaf

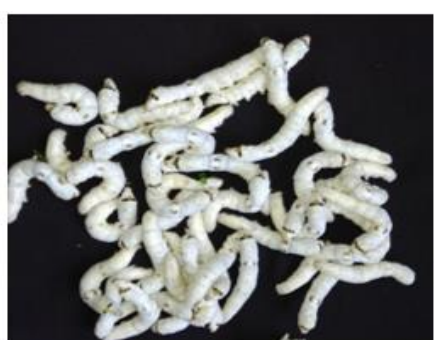

Silkworm larvae fed on egg albumen fortified mulberry leaf

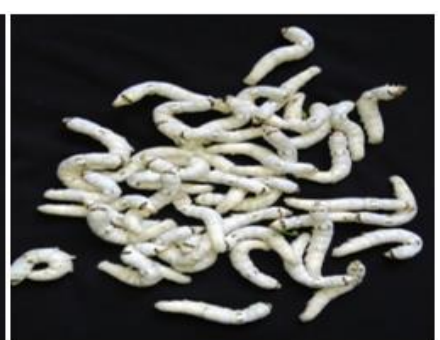

Control 


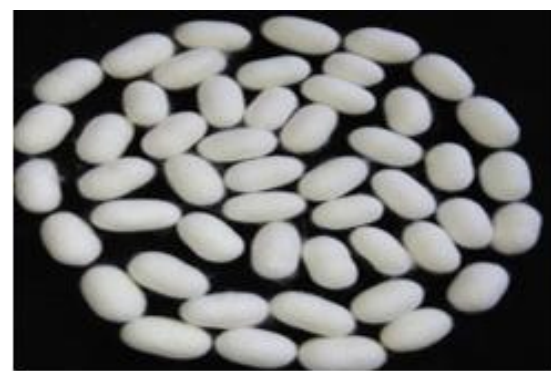

Cocoons of Silkworm larvae fed on egg albumen fortified mulberry leaf

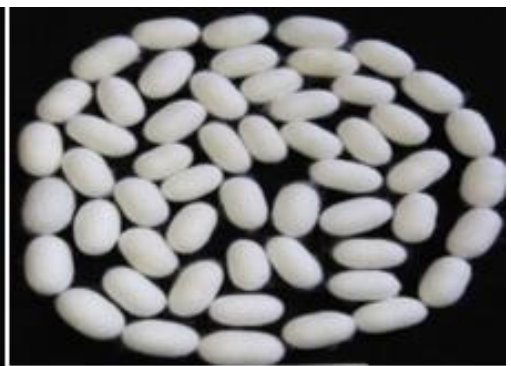

Control

Table 1: Impact of egg albumen fortified mulberry leaf on some rearing and cocoon yield parameters of Bombyx mori L. double hybrid (CSR6 $\times$ $\mathrm{CSR} 26) \times(\mathrm{CSR} 2 \times \mathrm{CSR} 27)$

\begin{tabular}{|c|c|c|c|c|}
\hline Treatments & $\begin{array}{c}\text { Total larval duration } \\
\text { (days) }\end{array}$ & $\begin{array}{l}\text { Weight of ten mature larvae on } \\
6^{\text {th }} \text { day }(\mathrm{g})\end{array}$ & $\begin{array}{c}\text { Cocoon yield by weight } \\
(\mathrm{kg})\end{array}$ & $\begin{array}{c}\text { Cocoon yield by } \\
\text { number }\end{array}$ \\
\hline $\mathrm{T}_{0}$ (Control) & $26.12^{\mathrm{a}}$ & $46.05^{\mathrm{d}}$ & $18.12^{\mathrm{e}}$ & 9012 \\
\hline $\mathrm{T}_{1}$ (Dipped in water) & $26.04^{\mathrm{a}}$ & $52.75^{\mathrm{c}}$ & $18.70^{\mathrm{d}}$ & 8872 \\
\hline $\mathrm{T}_{2}(5 \%$ egg albumen $)$ & $25.87^{\mathrm{b}}$ & $53.76^{\mathrm{c}}$ & $19.26^{\mathrm{c}}$ & 8790 \\
\hline $\mathrm{T}_{3}(10 \%$ egg albumen $)$ & $25.62^{\mathrm{c}}$ & $54.55^{\mathrm{c}}$ & $19.54^{\mathrm{c}}$ & 8816 \\
\hline $\mathrm{T}_{4}(15 \%$ egg albumen $)$ & $25.45^{\mathrm{d}}$ & $56.33^{b}$ & $20.35^{b}$ & 9121 \\
\hline $\mathrm{T}_{5}(20 \%$ egg albumen $)$ & $25.33^{\mathrm{e}}$ & $57.96^{\mathrm{a}}$ & $20.90^{\mathrm{a}}$ & 8920 \\
\hline $\mathrm{CD}$ at $5 \%$ & 0.10 & 1.43 & 0.53 & $\mathrm{NS}^{*}$ \\
\hline
\end{tabular}

*NS means non significant at $5 \%$ level

Table 2: Impact of egg albumen fortified mulberry leaf on cocoon parameters of Bombyx mori L. double hybrid $($ CSR6 $\times$ CSR26 $) \times($ CSR $2 \times$ CSR27)

\begin{tabular}{|c|c|c|c|}
\hline Treatments & Cocoon weight (g) & Shell weight (cg) & Shell Ratio (\%) \\
\hline $\mathrm{T}_{0}($ Control) & $2.06^{\mathrm{d}}$ & $40.60^{\mathrm{e}}$ & $20.20^{\mathrm{d}}$ \\
\hline $\mathrm{T}_{1}($ Dipped in water) & $2.14^{\mathrm{c}}$ & $43.35^{\mathrm{d}}$ & $21.26^{\mathrm{c}}$ \\
\hline $\mathrm{T}_{2}(5 \%$ egg albumen) & $2.17^{\mathrm{c}}$ & $45.30^{\mathrm{c}}$ & $21.48^{\mathrm{c}}$ \\
\hline $\mathrm{T}_{3}(10 \%$ egg albumen) & $2.18^{\mathrm{c}}$ & $47.15^{\mathrm{c}}$ & $21.76^{\mathrm{c}}$ \\
\hline $\mathrm{T}_{4}(15 \%$ egg albumen) & $2.25^{\mathrm{b}}$ & $49.75^{\mathrm{b}}$ & $22.10^{\mathrm{b}}$ \\
\hline $\mathrm{T}_{5}(20 \%$ egg albumen) & $2.32^{\mathrm{a}}$ & $52.65^{\mathrm{a}}$ & $22.52^{\mathrm{a}}$ \\
\hline CD at 5\% & 0.06 & 1.92 & 0.30 \\
\hline
\end{tabular}

\section{Conclusion}

Silkworm (Bombyx mori) was found to feed on the fortified leaves in the same way as in the non fortified leaves. It can be concluded from the study that, fortification of mulberry leaves with egg albumen resulted in improvement in commercial characteristics of silkworm (Bombyx mori L). There was improvement in larval weight and reduction in larval duration. Cocoon weight, Shell weight, Shell ratio and yield /10000 larvae by weight, showed significant improvement over control. Among different concentrations of egg albumen tested, 20 per cent egg albumen registered increased results in most of the parameters. Eggs are locally available with the farmers hence egg albumen can be used by the farmers to improve the leaf quality and in turn yield and quality of cocoons.

\section{Acknowledgement}

The author is grateful to College of Temperate Sericulture Mirgund, Skuast-K, Shalimar for providing materials required for research trial and is thankful to his guide for support and encouragement throughout research programme.

\section{References}

1. Chen Y. Variable tolerance of the silkworm Bombyx mori to atmospheric fluoride pollution. Fluoride. 2003; $36: 157-162$.
2. Chen CH, GU SH. Stage dependent effects of starvation on the growth, metamorphosis and ecdysteriodogenesis by the prothoracic glands during last larval instar of silkworm B. mori. J Insect. Phys. 2006; 52:968-974.

3. Needham J. Science and civilization in china, Cambridge university press, Cambridge, 1954, 1.

4. Anonymous. Note on the performance of Indian silk industry and functioning of Central Silk Board, 2019, 2628.

5. Anonymous. Annual report, Vision document and road map for cocoon and silk production in Jammu \& Kashmir. Sericulture Devlopment Department, 2019, 3.

6. Triubhuvan, Mathur SK. The morin factor in mulberry that attracted the Bombyx mori (L). Indian Silk. 1989; 28(5)39-40.

7. Patil SA. Nutritional management and quality improvement in sericulture-Keynote address. In: Nutritional Management and quality improvement in sericulture (ed. U.D. Bongale). KSSRDI, Thalaghattapura, Bangalore, 2003, 7-11.

8. House HC. The role of nutritional principles in biological control. Entomology. 1966; 98:1121-1134.

9. Legay JM. Recent advances in silkworm nutrition. Annual Review of Entomology. 1958; 3:75-86.

10. Nagesh, Deviah MC. Effect of Seri care-A feed additive on silk on silk productivity in silkworm, Bombyx mori L. Indian Journal of Sericulture. 1996; 35:67-68. 
11. Sengupta K, Singh BD, Mustafi JC. Nutrition of the silkworm, Bombyx mori L. Studies on the enrichment of mulberry leaf with various sugars, proteins, amino acids and vitamins for vigorous growth of the worm and increased cocoon crop protection. Indian Journal of Sericulture. 1972; 11:11-27.

12. Powrie WD, Nakai S. Characteristics of edible and fluids of animal origin egg. In: Food chemistry (Ed. Fennema, O.). New York: Marcel Dekker, 1985, 829-855.

13. Anonymous. Package of practices for silkworm rearing, 2003.

14. Horie Y, Watanabe K. Effect of various levels of dietary protein and supplementation with limiting amino acids on growth, haemolymph components and uric acid excretion in silkworm, Bombyx mori. Journal of Insect Physiology. 1983; 29:187-199.

15. Sekar K. Foliar supplementation of soya flour for improving the silk yield of mulberry silkworm, bombyx mori L. M.Sc. Thesis, Tamil Nadu Agricultural University, Coimbatore, 1995.

16. Murari M, Vijayendra M, Shashidhar KR, Narayanaswamy KC, Manjunath Gowda, Chandrashekar, S, Sudhakara SN. Influence of fortification of mulberry leaf with plant extracts on economic parameters of silkworm, Bombyx mori L. International Conference on Trends in Seribiotechnology (Abstract), Sri Krishnadevaraya University, Anantapur, Andhra Pradesh, 2008, 26-28, 75-76.

17. Sarker A. Effects of feeding different races of silkworn (Bombyx mori L.) with leaves varying in ploidy level. Sericologia. 1993; 33(1):25-34.

18. Hossain MS, Aftab Uddin MD, Saiful Islam MD, Abdul Alim MD. Effect of Cow Milk on the Growth and Economic Traits of Silkworm (Bombyx mori). International Journal of Scientific \& Engineering Research. 2015; 6(3):517-520.

19. Alagumalai K, Hepshyba CSS, Ramaraj P. Bran of pulses as extra nutrient to silkworm. Indian Silk. 1991; 30(6):10-11.

20. Mala N, Sadatilla F, Babu H. Strengthening of sericulture industry through fortification of mulberry leaves to enhance commercial cocoon characteristics of silkworm. Agriculture Update. 2017; 12:210-217.

21. Nalini R, Gunathilagaraj K, Radha NV, Natarajan K. Supplementation of protein through soybean flour (Defatted) for mulberry silkworm. Second National Symposium on prospects and problems of Sericulture in India. $7^{\text {th }}-9^{\text {th }}$ march 1994. Madras university, 1994, 54.

22. Rajanna KL, Puttaraju HP. Food utilization, growth and their relative rates in the lines of silkworm, Bombyx mori L. selected for pupal weight. Entomol. 2000; 25(4):291301.

23. Amit K, Govind M, Hugur II. Bio-potentiality of Waste pupae bio-protein as nutritional supplement to improve the economic traits in B. mori L. International Journal of Scientific Research. 2015; 4(11):75-76.

24. Sujatha K, Rao AP. Effect of Curcuma longa (turmeric) on the commercial characters of multivoltine silkworm, Bombyx mori L. J Exptl. Zool. 2003; 6(1):109-111.

25. Chamundeswari P, Radhakrishnaiah K. Effect of Zinc and Nickel on the silkworm, Bombyx mori L. Sericologia. 1994; 34(2):327-332.

26. Majumdar AC, Medda AK. Studies on the thyroxin and vitamin B2, induced changes in the cycle of Silkworm,
Bombyx mori. Indian $\mathrm{J}$ of Physiology and Applied Science. 1995; 29:1-13.

27. Mahesha HM. Extrafoliation of aqueous extracts of botanicals on silkworm, Bombyx mori L. M. Sc. (Seri.) Thesis, UAS, Dharwad, 1999, 83.

28. Fatima S, Shivashankar R, Chinnaswamy KP, Rashmi K, Saritha Kumari S. In-vitro and In-vivo efficacy of Aloe vera barbadensis gel against the fungus Beauveria bassiana infecting silkworm Bombyx mori L. International Conference on Trends in Seribiotechnology, (Abstract), Sri Krishnadevaraya University, Anantapur, Andhra Pradesh, 2008, 63. 